\title{
Proposal of Enterobacteraceae nom. nov. as a Substitute for the Illegitimate but Conserved Name Enterobacteriaceae Rahn 1937
}

\author{
Request for an Opinion
}

\author{
S. P. LAPAGE \\ National Collection of Type Cultures, Central Public Health Laboratory, London NW9 5HT, England
}

\begin{abstract}
Although the name Enterobacteriaceae Rahn 1937 was not formed in accordance with the rules of nomenclature, it was conserved by the Judicial Commission in 1958, with Escherichia Castellani and Chalmers 1919 as the type genus. However, the Judicial Commission recently agreed that exceptions to the formation of names of taxa between subclass and genus would not be accepted. Hence, it is here proposed that the Judicial Commission issue an Opinion changing the type genus of this family from Escherichia to Enterobacter Hormaeche and Edwards 1960 and the family name from Enterobacteriaceae to Enterobacteraceae nom. nov.
\end{abstract}

The Judicial Commission of the International Committee on Systematic Bacteriology noted in Minute 29 of its 1973 meetings (8) that the family name Enterobacteriaceae Rahn 1937 (9) was not formed in accord with Rule 9 of the recently (1975) revised International Code of Nomenclature of Bacteria (7) in that it was not based on the name of the type genus of the family. The reason for this situation is that the family name Enterobacteriaceae Rahn had been conserved with type genus Escherichia Castellani and Chalmers 1919 (1) in Opinion 15 issued by the Judicial Commission (5) in 1958 as a specific exemption to Rule 9 . As indicated in the above-mentioned minute, the Commission indicated that it would be willing to consider a recommendation on this matter.

At the XII International Congress for Microbiology (Munich, 1978), however, the Commission (2) agreed that no exception to Rule 9 of the (1975) revised International Code of Nomenclature of Bacteria would be permitted (Minute 9) and that the name Enterobacteriaceae should be rejected and the name Enterobacteraceae should be conserved and used in place of Enterobacteriaceae (Minute 29). This course has the merit of producing a minimal disturbance of existing nomenclature, because for practical purposes the only change is a small difference in spelling, i.e., the omission of the letter " $i$ " from the presently used family name. Such a change is unlikely to cause much difficulty for future bacterial systematists, because it should be no more disturbing than changes produced by emendation of the spelling of names that have been inadvertently spelled incorrectly (e.g., emendation of Hemophilus to Haemophi- lus). The change does not affect the first part of the word, and therefore it should seldom disturb the position of the family name in alphabetized lists.

This course seems to lead to less disturbance than the alternative of retaining the present type genus and changing the family name to Escherichiaceae. The genus Enterobacter appears to be quite typical of the family, and it is very adequately known and defined. It has a welldefined type species, Enterobacter cloacae (Jordon 1890) Hormaeche and Edwards 1960, with an accepted neotype strain, CDC 279-56 (= NCTC 10005 = ATCC 13047), proposed by Hormaeche and Edwards (3). The name Enterobacter has been conserved (6).

It appears, however, that the family name Enterobacteraceae has never been validly published. This name is, therefore, formally proposed here as a new name.

\section{Enterobacteraceae nom. nov.}

Gram-negative, rod-shaped cells which are motile and peritrichous or nonmotile. Endospores are not produced. Aerobic, facultatively anaerobic. Grow readily on peptone media; occasionally have special growth requirements. Metabolism is respiratory and fermentative; acid is produced from glucose and other carbohydrates. Most species are catalase positive and oxidase negative and reduce nitrates to nitrites. The guanine-plus-cytosine content of the deoxyribonucleic acid ranges from 35 to $60 \mathrm{~mol} \%$.

The type genus is Enterobacter Hormaeche and Edwards 1960 (nom. cons.: Opinion 28, Judicial Commission [6]).

An Opinion of the Judicial Commission is 
requested on the proposal that the type genus of the family currently named Enterobacteriaceae be the genus Enterobacter and that the name of this family be Enterobacteraceae; the Judicial Commission is therefore requested to override Opinion 15 (1976 revision, International Code of Nomenclature of Bacteria, p. 91; Int. Bull. Bacteriol. Nomencl. Taxon. 8:73-74) in favor of this proposal.

\section{REPRINT REQUESTS}

Address reprint requests to: Dr. S. P. Lapage, National Collection of Type Cultures, London NW9 5HT, England.

\section{LTERATURE CITED}

1. Castellani, A., and A. J. Chalmers. 1919. Manual of tropical medicine, 3rd ed. Williams Wood and Co., New York.

2. Holt, J. G. 1979. International Committee on Systematic Bacteriology Judicial Commission. Minutes of the Meeting, 3 September 1978, Munich, West Germany. Int. J. Syst. Bacteriol. 29:267-269.

3. Hormaeche, E., and P. R. Edwards. 1960. A proposed genus Enterobacter. Int. Bull. Bacteriol. Nomencl. Taxon. 10:71-74.

4. Jordan, E. O. 1890. A report on certain species of bacteria observed in sewage. Rep. Mass. Board Publ. Health 1890:821-844.

5. Judicial Commission. 1958. Opinion 15. Conservation of the family name Enterobacteriaceae, of the name of the type genus and designation of the type genus and designation of the type species. Int. Bull. Bacteriol. Nomencl. Taxon. 8:73-74.

6. Judicial Commission. 1963. Opinion 28. Rejection of the bacterial generic name Cloaca Castellani and Chalmers and acceptance of Enterobacter Hormaeche and Edwards as a bacterial generic name with type species Enterobacter cloacae (Jordan) Hormaeche and Edwards. Int. Bull. Bacteriol. Nomencl. Taxon. 13:38.

7. Lapage, S. P., P. H. A. Sneath, E. F. Lessel, V. B. D. Skerman, H. P. R. Seeliger, and W. A. Clark (ed.). 1975. International code of nomenclature of bacteria. American Society for Microbiology, Washington, D.C.

8. Lessel, F. F. 1974. Judicial Commission of the International Committee on Systematic Bacteriology. Minutes of the meeting, 29 August 1973, Jerusalem, Israel. Int. J. Syst. Bacteriol. 24:379-380.

9. Rahn, O. 1937. New principles for the classification of bacteria. Zentralbl. Bakteriol. Parasitenkd. Infektionskr. Hyg. Abt. 2 96:273-286. 